\title{
Disparities in Agricultural Practices According to Cashew Nut Production Regions in Côte d'Ivoire and Probable Incidence on Nut Quality
}

\author{
Koffi Yao Stephane1, Kouadio James Halbin ${ }^{1,2 *}$, Soya Joseph ${ }^{2}$ \\ ${ }^{1}$ Research Group of Crop Production Quality Management, Laboratory of Agrovalorisation, UFR Agroforesterie, Jean Lorougnon \\ Guédé University, Daloa, Côte d'Ivoire \\ ${ }^{2}$ Laboratory of (Bio) Toxicology and Industrial Hygiene, DPPSST, CNPS Abidjan, Abidjan, Côte d'Ivoire \\ Email: jameshalbink@yahoo.fr
}

How to cite this paper: Stephane, K.Y., Halbin, K.J. and Joseph, S. (2021) Disparities in Agricultural Practices According to Cashew Nut Production Regions in Côte d'Ivoire and Probable Incidence on Nut Quality. Agricultural Sciences, 12, 1168-1183.

https://doi.org/10.4236/as.2021.1210075

Received: July 3, 2021

Accepted: October 25, 2021

Published: October 28, 2021

Copyright $\odot 2021$ by author(s) and Scientific Research Publishing Inc. This work is licensed under the Creative Commons Attribution International License (CC BY 4.0).

http://creativecommons.org/licenses/by/4.0/

(c) (i) Open Access

\begin{abstract}
Improving the quality of agricultural products depends largely on production process. In the absence of data on farmers' practices and the average quality of cashew nuts in Côte d'Ivoire, the present study aimed to provide a detailed description of the cashew nut production process. Thus, a survey was carried out in the zones of Mankono, Dabakala and Bondoukou among 386 cashew producers selected at random and interviewed using the face-to-face technique. The results revealed that intercropping was practiced in cashew cultivation $(42 \%-62 \%$ of the producers), modern cultivation technique $(72 \%$ $98 \%$ of the producers) but with rare use of selected seeds $(8 \%-20 \%$ of the producers), labour/ha during nut harvesting (2.6 - 12 workers/ha). Concerning the harvesting process, the time taken to pick the nuts varies from 1 to 14 days; the use of pesticides during harvesting ( $14 \%$ to $97 \%$ of the producers) and the absence of sorting of the nuts in $42 \%$ of the Mankono producers justify the probable conservation of defective and immature nuts in their production. For drying, the main dryers were the slatted table, the cemented surface and the tarpaulin, but other dryers were found such as the mosquito net, the propylene rice bag, the fertiliser bag and the black bag. Generally, the drying time of cashew nuts was very short: 2 days $(43 \%-77 \%$ of the producers interviewed) but surprisingly 1 day ( $7 \%-27 \%$ of the producers interviewed). For Mankono, the use of chemicals was permanent during all stages of the cashew production process. Overall, the results suggest the need to assess the real impact of farmers' practices on the quality of cashew nuts from Côte d'Ivoire.
\end{abstract}

\section{Keywords}

Cashew-Nuts, Production-Process, Quality-of-Nuts, Pesticides 


\section{Introduction}

The Anacardium species are native to tropical America [1] and have significant economic importance throughout the world, principally because of two of its natural products namely the cashew nut and apple [2]. The cashew represents Africa which provides $50 \%$ of the world production of raw cashew nuts, a great opportunity through the export of its nuts [3] [4].

Long time used in Côte d'Ivoire as a reforestation plant due to its rapid growth and its rusticity, the cashew tree was until the early 1990s exploited for its wood [5] [6]. But, since the beginning of the 2000s, cashew plantations have emerged gradually as income-generating speculation in front of cotton [5] [6]. Thus, the production of cashew has been very intensive in Côte d'Ivoire since 2015 with annual productions estimated at 700 thousand tons representing a rate of $21 \%$ of the world's offer. Côte d'Ivoire is currently the world leading producer and exporter country of cashew. More than 250 thousand producers are concerned by cashew which represents the main source of income for approximately 1.5 million Ivorian people [6].

Despite the enormous potential for cashew revenue in Côte d'Ivoire, the cashew production is characterized not only by low yields, but also by a less competitive quality of nuts internationally [7]. Indeed, the production of cashew as other crops remained heavily dependent on climatic conditions [8]. The rainfall irregularities and temperature increasing made cashew tree cultivation vulnerable to undesirable organisms (weeds, insects, fungi, bacteria, etc.) and which were probably one cause of significant yields decrease and the depreciation of nut quality [9]. It had been also reported that the diversity of ecological regions combined with poor harvest and post-harvest practices are a major constraint to improve the quality of produced nuts [4] [10] [11]. For example, nutritional components degradation [12] [13] and contaminants such as mycotoxins occurrence in foods were strongly linked to poor agricultural practices [14] [15] probably by post-harvest metabolism mechanism [12]. Thus, the major source of food insecurity in Africa is post-harvest food loss. Pre- and post-harvest food losses in Africa are higher than the global average and impact more severely on already endangered livelihoods [16]. It has been estimated that at least $10 \%$ of the continent's crop productivity was lost on and off farm [16]. In previous studies performed in African countries on horticultural crops, the levels of crops loss were up to $45.32 \%$ for tomato followed by mango (43.53\%) and coffee (15.75\%). Post-harvest loss ranging from $20 \%$ to $50 \%$ was recorded in between marketing and consumption [17] [18]. This is because most farmers do not have access to appropriate crops production technologies combined to erratic climatic conditions such as heavy rains, droughts and other related factors [19].

In Côte d'Ivoire, despite the measures taken to improve the quality of cashew nuts, it remains poor or classed acceptable [20] [21] because of the moisture levels often above the $10 \%$, the standard of water content. In addition, the abusive use of pesticides occurred in the practices of farmers from several main regions 
of cashew production [22]. That could explain the Ivorian cashew nuts quality degradation [20] and an Out-turn average ranged between 46 and $48 \mathrm{lbs}$ compared to 47 to $49 \mathrm{lbs}$ in Benin and Nigeria and 50 to $52 \mathrm{lbs}$ in Senegal and Guinea-Bissau respectively [4] [23]. Out-turn is mainly related to cashew nuts graining [21] [23], to physical and morphometric traits [24] [25] and to the defects of the nuts produced. Since poor harvest and post-harvest practices are a major obstacle to improve the quality of produced nuts [4] [10] [11], it appears very urgent for the Côte d'Ivoire to have sufficient information about these steps of cashew production system. Previous studies in this domain in Côte d'Ivoire and other African countries were rare. Those available in Côte d'Ivoire concerned essentially the genotypic screening of high-yield cashew nuts [21] and an evaluating of cashew pests [9]. The few data available on pre or postharvest practices concerned those reported from Ghana [19]. In this study focused on assessment of postharvest handling effects on quality of cashew nuts and kernels, it had been revealed that disparities in period of cashew fruits picking, nuts drying processing and duration as well as storage [19]. In comparison to those finding from Ghana, we hypothesized that the practices of farmers from Côte d'Ivoire may be more or less different. The farmers from East of Côte d'Ivoire could have significantly the same practices due to their geographical proximity with Ghana. But, farmers from the North of Côte d'Ivoire could have other practices as previously reported such as abundant pesticides uses in cashew production [22] similar to cotton production [26]. In this context, the present study focused on the description of pre and postharvest technologies of cashew nut represented a major step to collect sufficient information necessary to improve the cashew nuts quality and ensure the sustainability of this speculation in Côte d'Ivoire.

\section{Materials and Methods}

\subsection{Study Area}

The present survey was conducted in the three main areas of cashew nut production in Côte d'Ivoire namely Mankono (NorthWest), Dabakala (North Center) and Bondoukou (East). A stratification of localities based on the importance of cashew nut production was performed and 20 localities were randomly selected among the total list of producers conformed to our criteria. A total of 805 farmers have been identified.

\subsection{Study Method and Technique}

The present survey is a cross-sectional study with a descriptive purpose which was conducted during the period from April 2017 to August 2018. A structured questionnaire in 2 parts was used to collect the data. The first part was devoted to describing the characteristics of cashew plantations and the second part was focused on agricultural practices of farmers.

As previously described [16] [27] and reported in our recent study [22], a representative sample of 386 producers on the basis of a total of 805 was estab- 
lished such as Mankono (147), Dabakala (125) and Bondoukou (114) (Table 1). After determining the sample size, a systematic random sampling was used to select producers satisfying the inclusion criteria as described above.

Table 1. Sample sizes according to areas covered.

\begin{tabular}{ccccc}
\hline Department & $\begin{array}{c}\text { Number of covered } \\
\text { area }\end{array}$ & $\begin{array}{c}\text { Total number of } \\
\text { identified producers }\end{array}$ & $\begin{array}{c}\text { number of surveyed } \\
\text { producers }\end{array}$ & Polling rate (\%) \\
\hline Mankono & 10 & 345 & 147 & 43 \\
Dabakala & 5 & 260 & 125 & 48 \\
Bondoukou & 5 & 200 & 114 & 57 \\
\hline
\end{tabular}

The data of our study were collected by administering a face-to-face questionnaire following by an incognito observation in order to verify the data from the questionnaires.

\subsection{Target Population}

As described in our recent study [22], the present study was exclusively about the cashew producers belonging to one of the 20 localities of strong productions identified by our partners namely the National Rural Development Support Agency (ANADER) and the Cooperative Society of Agricultural Producers of Bondoukou (COPABO). In addition, the investigated producer must have a farm in production with a higher or equal to 1 hectare in order to include in the study only representative producers.

\subsection{Variables of the Study}

Our previous study described the socio-demographic variables (gender, age, level of education and knowledge) of farmers [22]. In the present study, three groups of variables have been followed namely the information on the plantations (typology and size, seed origin and sowing method, workers origin during harvest period), the harvest (frequency of fruits picking, nuts collection technique, nuts sorting or not, pesticides use or not) and the postharvest practices (drying processing and duration, storage and possible pesticides use).

\subsection{Data Processing and Analysis}

After processing the survey sheets, the data were coded, entered and analyzed using Sphinx 4.5.0.30 and Excel version 2010. The data were summarized in the form of tables and figures.

\section{Results}

\subsection{Characteristics of Cashew Plantations and Number of Workers per Hectare}

\subsubsection{Typology of Plantations}

The typology of plantations and associated cultivation techniques were summa- 
rized in Table 2. The pure cashew plantations or plantations with exclusive cashew represented 36.9\% in Bonkoukou, 57.8\% in Dabakala and $45.9 \%$ in Mankono respectively. The non-pure cashew plantations represented $54.1 \%$ in Bondoukou, $42.2 \%$ in Mankono and 63.4\% in Mankono. But in Dabakala, associated crops were largely intermittent (37\%) while the culture association was preserved in Bondoukou and in Mankono. Concerning the cultivation techniques, they were largely modern above all in Mankono (98.2\%). But, traditional practices remained significant in Bondoukou (25.2\%) and Dabakala (27.6\%).

Table 2. Typology of plantations and nature of cultivation techniques ( $\mathrm{n}=386$ producers).

\begin{tabular}{lcccc}
\hline & & $\begin{array}{c}\text { Mankono } \\
(\%)\end{array}$ & $\begin{array}{c}\text { Dabakala } \\
(\%)\end{array}$ & $\begin{array}{c}\text { Bondoukou } \\
(\%)\end{array}$ \\
\hline \multirow{3}{*}{ Type of plantation } & Pure cashew tree orchard & $36.9^{\mathrm{a}}$ & $57.8^{\mathrm{b}}$ & $45.9^{\mathrm{c}}$ \\
& Annual associated crops & $41.8^{\mathrm{a}}$ & $5.2^{\mathrm{b}}$ & $45^{\mathrm{a}}$ \\
& Intermittent associated crops & $21.6^{\mathrm{a}}$ & $37^{\mathrm{b}}$ & $9.1^{\mathrm{c}}$ \\
\hline \multirow{2}{*}{ Cultivation techniques } & Traditional practice & $25.2^{\mathrm{a}}$ & $27.6^{\mathrm{a}}$ & $1.8^{\mathrm{b}}$ \\
& Modern practice & $74.8^{\mathrm{a}}$ & $72.4^{\mathrm{a}}$ & $98.2^{\mathrm{b}}$ \\
\hline
\end{tabular}

Data are average values \pm standard deviation. ${ }^{\mathrm{a}, \mathrm{b}, \mathrm{c}}$ average of the same line with different letters are significantly different $(\mathrm{p}<0.05)$.

\subsubsection{Distribution of Size of Cashew Orchards According to Production Areas}

Figure 1 summarizes information about the size of plantations. $64.71 \%$ interviewed farmers in Dabakala and 58.62\% in Bondoukou have orchards with surfaces between 1 and 5 . These values revealed that over half of farmers were small cashew growers as compared to those from Mankono where $64.28 \%$ of farmers had large plantations ( $>5 \mathrm{ha}$ ). In addition, $17 \%$ of total interviewed farmers from Mankono had plantations of size $>15$ ha against 3.45\% in Bondoukou and $0 \%$ in Dabakala.

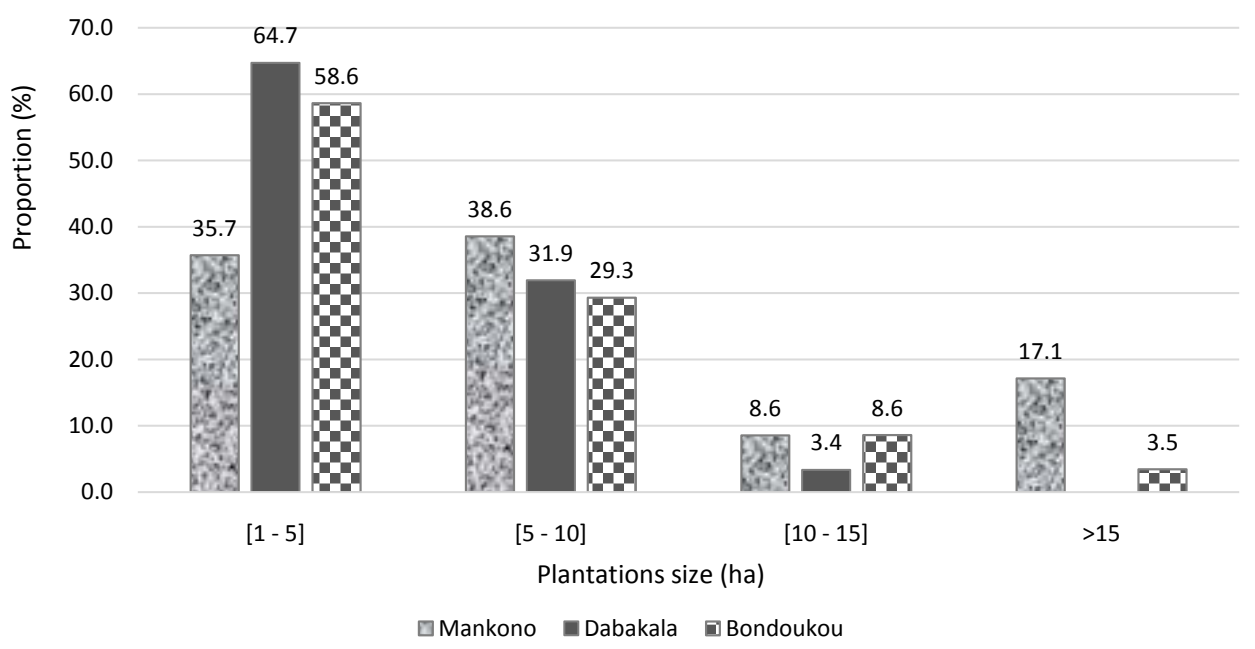

Figure 1. Size of cashew orchards in the three production areas. 


\subsubsection{Seed and Sowing Method}

Analyses (Figure 2) revealed that two seeding methods were used by producers when creating new cashew tree plantations. These were essentially direct seeding, which was $87.4 \%$ in Mankono, $91.2 \%$ in Dabakala and $97.4 \%$ in Bondoukou, and planting by nursery. However, the low use of improved varieties of cashew nuts was noted among the producers in Mankono (10.3\%), Bondoukou (19.1\%) and Dabakala (7.8\%). In fact, more than $80 \%$ of the orchards were established with local varieties.

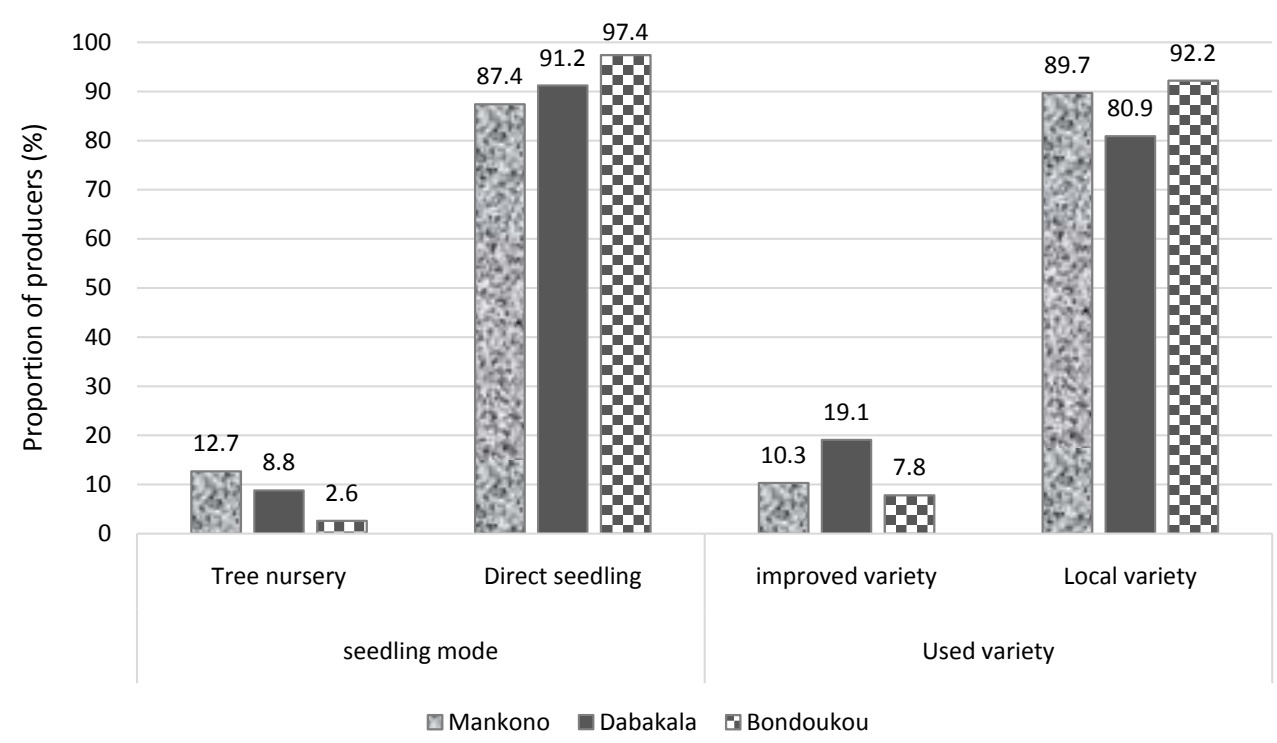

Figure 2. Seedling mode and crops type of cashew tree.

\subsubsection{Workers Origin and Their Density per Hectare during Harvesting}

Table 3 summarized the origin of workers, the employment during nut harvesting and the density of workers; that is number of workers/ha during nut harvesting. Our results revealed that the size of plantations ranged from 0.25 to 15 ha in both Bondoukou and Dabakala but from 0.3 to 40 ha in Mankono. In farm owners' families, the number of workers during harvesting, ranged from 1 to 16 in Bondoukou, from 1 to 20 in Mankona and from 1 to 22 in Dabakala. Thus, additional workers were employed and the numbers ranged from 1 to 23 in Bondoukou, from 1 to 43 in Dabakala and from 1 to 90 in Mankono. Despite the high number of additional workers in Mankono (up to 90 workers during the harvest period), the number of workers per hectare was lower and ranged from 2.75 to 6.67 workers per hectare. The values of Bonkoukou and Dabakala ranged from 2.6 to 12 and from 4.33 to 8 workers per hectare respectively.

Table 3. Description of cashew nut orchard holdings in the main cashew nut production areas.

\begin{tabular}{|c|c|c|c|c|c|c|c|c|c|c|c|c|}
\hline \multirow{2}{*}{$\begin{array}{l}\text { Production } \\
\text { areas }\end{array}$} & \multicolumn{3}{|c|}{ Area of plantations (ha) } & \multicolumn{3}{|c|}{$\begin{array}{c}\text { Numbers of active members } \\
\text { of family owners }\end{array}$} & \multicolumn{3}{|c|}{$\begin{array}{l}\text { Employment during nut } \\
\text { harvesting }\end{array}$} & \multicolumn{3}{|c|}{$\begin{array}{c}\text { Density of workers (workers/ha) } \\
\text { during nut harvesting }\end{array}$} \\
\hline & Max & Min & Average & Max & Min & Average & $\operatorname{Max}$ & Min & Average & $\operatorname{Max}$ & Min & Average \\
\hline Mankono & 40 & 0.3 & $4.67 \pm 5.49^{c}$ & 20 & 1 & $7.52 \pm 4.77^{\mathrm{b}}$ & 90 & 1 & $15.28 \pm 15.37^{\mathrm{b}}$ & 6.67 & 2.75 & $4.88 \pm 3.67^{\mathrm{a}}$ \\
\hline
\end{tabular}




\section{Continued}

\begin{tabular}{cccccccccccccc}
\hline Dabakala & 15 & 0.25 & $2.62 \pm 2.02^{\mathrm{b}}$ & 22 & 1 & $5.26 \pm 2.61^{\mathrm{a}}$ & 43 & 1 & $10.43 \pm 8.81^{\mathrm{a}}$ & 8 & 4.33 & $5.99 \pm 5.68^{\mathrm{a}}$ \\
Bondoukou & 15 & 0.25 & $3.41 \pm 2.75^{\mathrm{a}}$ & 16 & 1 & $5.35 \pm 2.83^{\mathrm{a}}$ & 23 & 2 & $6.51 \pm 4.45^{\mathrm{a}}$ & 12 & 2.6 & $3.78 \pm 2.65^{\mathrm{a}}$ \\
\hline
\end{tabular}

Data are average values \pm standard deviation. ${ }^{\mathrm{a}, \mathrm{b}, \mathrm{c}}$ average of the same line with different letters are significantly different $(\mathrm{p}<0.05)$.

\subsection{Harvest Technique}

\subsubsection{Frequency of Nut Collection}

Our results revealed that the frequency of nut picking varied according to the farmers and the regions of production (Figure 3). The frequency varied from 1 to 14 days in Makono, from 1 to 7 days in Dabakala and from 1 to 3 days in Bondoukou. An analysis of the results showed that more than $76 \%$ of farmers from Bondoukou picked nuts at the latest every day after the fall of fruits. In Dabakala, the picking delay was three days in half of farmers (39.50\%) and 7 days in the main nut production area in Côte d'Ivoire, with $(42.50 \%)$ of adoption rate.

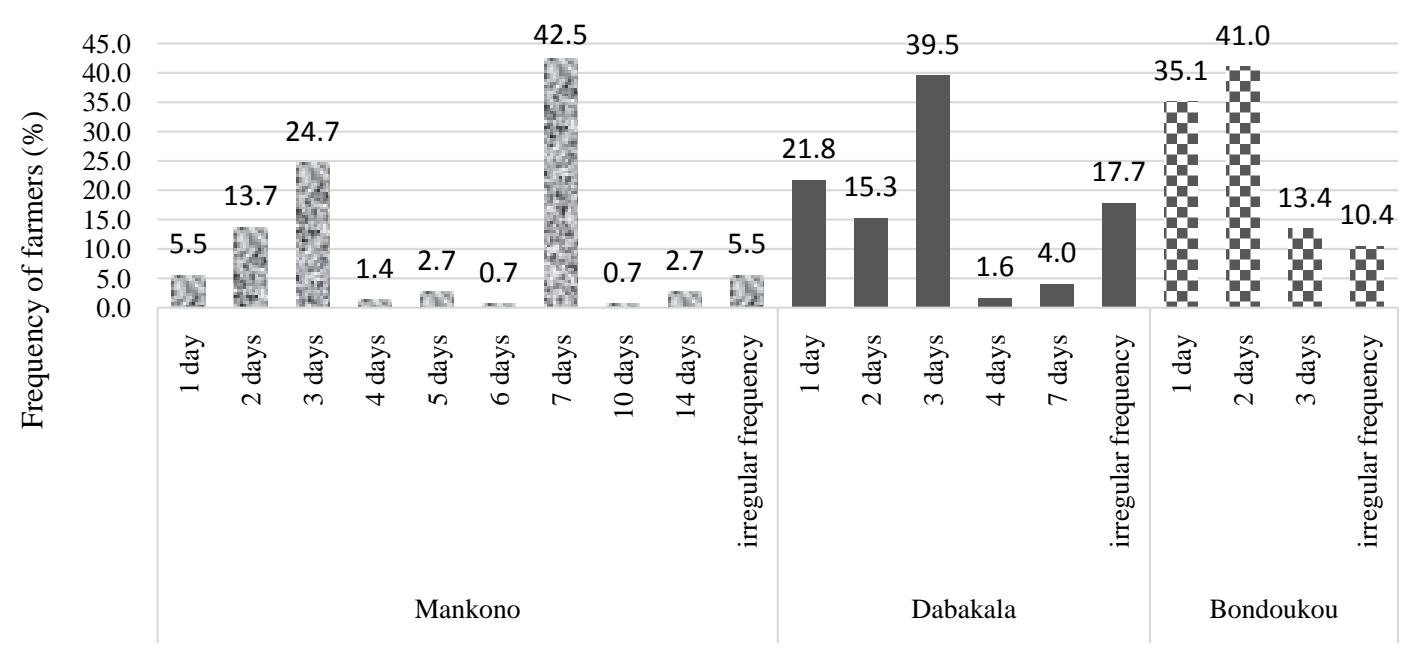

Time limit of nut picking

Figure 3. Frequency of nut picking according to the three regions Mankono, Dabakala and Bondoukou.

\subsubsection{Pesticides Used During Harvesting}

Table 4 shows that $98 \%$ and $84 \%$ of farmers from Mankono and Dabakala respectively used chemical pesticides during harvesting against only $14 \%$ of farmers from Bondoukou. Pesticides that were used concerned essentially herbicides: $88 \%$ in Bondoukou, $82 \%$ in Mankono and $90.52 \%$ in Dabakala. The use of insecticides varies from $7.69 \%$ to $11.76 \%$ of farmers. Fungicides were exclusively used in Mankono as $9.47 \%$ of farmers.

Table 4. Disparities in practices about using of pesticides during harvesting.

\begin{tabular}{cccccc}
\hline & & Mankono (\%) & Dabakala (\%) & Bondoukou (\%) & Average (\%) \\
\hline $\begin{array}{c}\text { Chemical treatment } \\
\text { during harvesting }\end{array}$ & yes & $97.96^{\mathrm{c}}$ & $84^{\mathrm{b}}$ & $14.04^{\mathrm{a}}$ & 68.65 \\
& No & $2.04^{\mathrm{c}}$ & $16^{\mathrm{b}}$ & $85.96^{\mathrm{a}}$ & 31.35 \\
\hline
\end{tabular}




\section{Continued}

\begin{tabular}{cccccc}
\hline & Herbicides & $82.84^{\mathrm{a}}$ & $90.52^{\mathrm{a}}$ & $88.24^{\mathrm{a}}$ & 86.09 \\
Nature of & Insecticides & $7.69^{\mathrm{a}}$ & $9.48^{\mathrm{a}}$ & $11.76^{\mathrm{a}}$ & 8.61 \\
used pesticides & Fungicides & $9.47^{\mathrm{b}}$ & $0.00^{\mathrm{a}}$ & $0.00^{\mathrm{a}}$ & 5.30 \\
\hline
\end{tabular}

Data are average values \pm standard deviation. a,b,c Average of the same line with different letters are significantly different $(\mathrm{p}<0.05)$.

\subsubsection{Technique of Nut Separation from Apple and Nuts Defectives Sorting}

According to Table 5, the practice of sorting defective nut level ranged from $57.14 \%$ to $90.53 \%$. Most of farmers from Bondoukou (90.35\%) adopted this practice in contrast to Mankono where a significant number of farmers (42\%) ignored it. The technique of nut separation from apple was essentially torsional separating in the three regions, despite $1.36 \%$ of farmers from Mankono who applied the technique by the wire.

Table 5. Nuts separation technique and levels (\%) of sorting defective nuts.

\begin{tabular}{|c|c|c|c|c|c|}
\hline & & Mankono ( & bakala (\%) & Bondoukou (\%) & Average (\%) \\
\hline \multirow{2}{*}{$\begin{array}{l}\text { Sorting of defective } \\
\text { nuts }\end{array}$} & Yes & $57.14^{\mathrm{c}}$ & $72^{\mathrm{b}}$ & $90.35^{\mathrm{a}}$ & 71.76 \\
\hline & No & $42.86^{c}$ & $28^{\mathrm{b}}$ & $9.65^{\mathrm{a}}$ & 28.24 \\
\hline \multirow{2}{*}{$\begin{array}{l}\text { Nut separation } \\
\text { techniques }\end{array}$} & Torsional separating & $98.64^{\mathrm{a}}$ & $99.20^{\mathrm{a}}$ & $100^{\mathrm{a}}$ & 99.22 \\
\hline & By the wire & $1.36^{\mathrm{a}}$ & $0.80^{\mathrm{a}}$ & $0.00^{\mathrm{a}}$ & 0.78 \\
\hline
\end{tabular}

Data are Average values \pm standard deviation. ${ }^{\mathrm{a}, \mathrm{b}, \mathrm{c}}$ Average of the same line with different letters are significantly different $(\mathrm{p}<0.05)$.

\subsection{Post-Harvest Processing}

\subsubsection{Different Dryers Used for Cashew Nuts}

As shown by Figure 4 and Figure 5, the type of dryers seems identical but with different using level according to the regions. Different dryers found concerned essentially drying rack table, concrete floor and tarpaulin. But other dryers have been found such as mosquito net, rice bag in propylene, fertilizers bag and black bag. For Mankono, the two major dryers were tarpaulin (64.16\%) and concrete floor $(15.03 \%)$ following by mosquito net $(6.36 \%)$ respectively. From Dabakala, three dryers mainly found were tarpaulin (51.89\%), drying rack table $(25.57 \%)$ and concrete floor (11.28\%) following by black bag (5.26\%) respectively. From Bondoukou, four predominant dryers have been identified such as drying rack table (39.36\%), tarpaulin (26.59\%), concrete floor (21.81\%) and black bag (9.57\%).

\subsubsection{Drying Duration Adopted by Producers and Nuts Sorting or Not during the Drying}

Our results revealed that the drying time adopted by farmers varied from 1 to 4 days (Figure 6). But, a drying duration of 2 days was preferentially practiced by farmers (72.81\%) from Bondoukou, (48.8\%) from Dabakala and (43.54\%) from Mankono respectively. The duration of 3 days was secondary adopted by farmers 
from Bondoukou (20.18\%) and Dabakala (22.4\%) respectively. However, duration of 1 day was secondary adopted by farmers from Mankono (27.89\%) and tertiary at Dabakala (19.2\%), this was rare in Bondoukou (7.02\%). Finally, only $1.36 \%$ of farmers from Mankono and $4.80 \%$ from Dabakala dried their product at this drying duration.

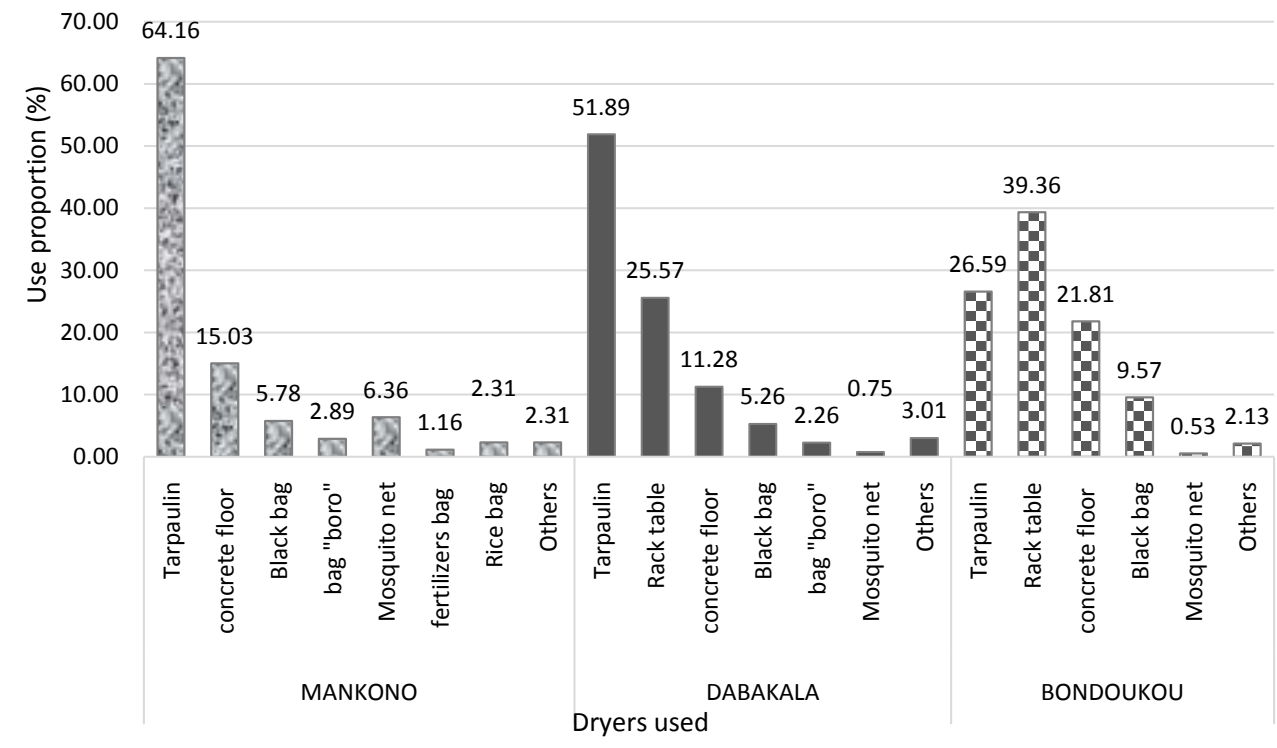

Figure 4. Different dryers using levels (\%) according to regions of cashew nuts production.
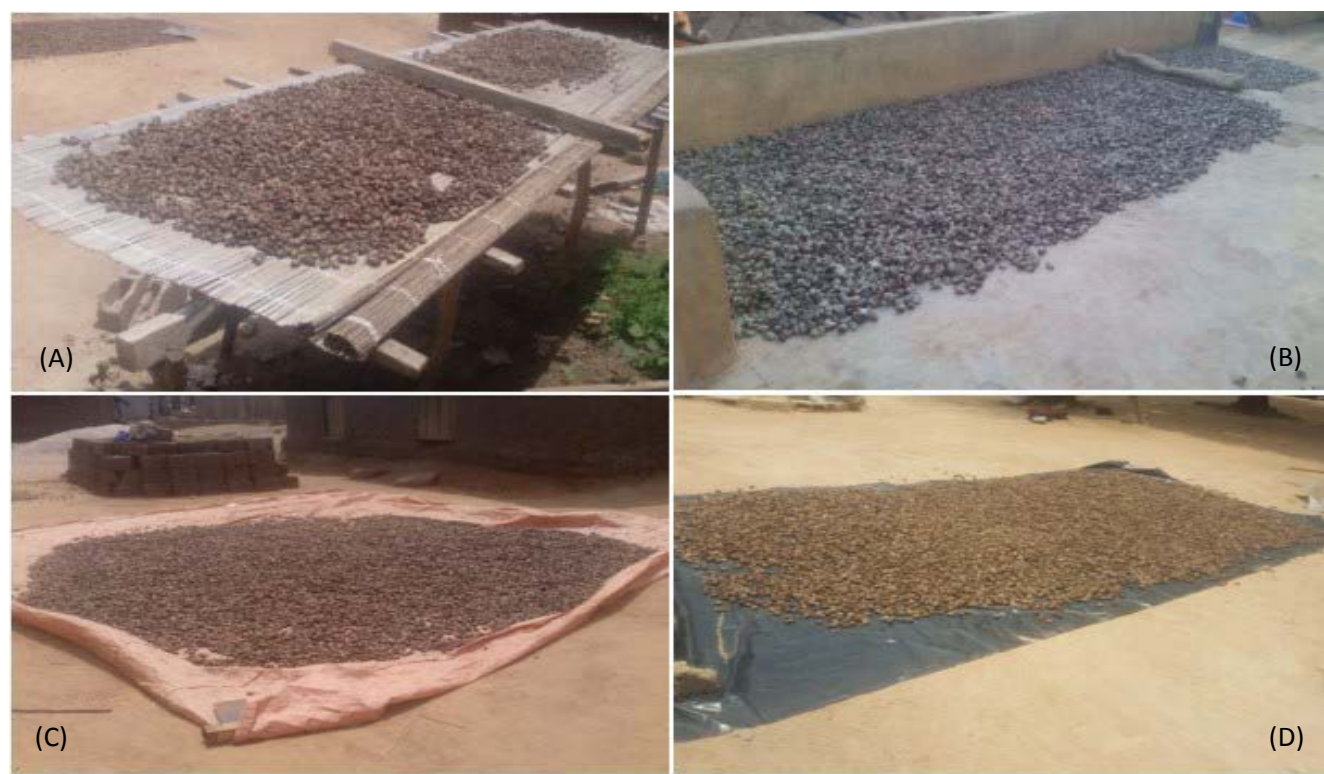

Figure 5. Main used dryers in the production of raw cashew nuts: (A) Rack table; (B) Concrete floor; (C) Tarpaulin and (D) Black bag (Photography, Koffi 2018).

During the drying process, $77.19 \%$ of farmers from Bondoukou practiced the sorting of nuts against $66.40 \%$ from Dabakala and only 31.97\% from Mankono respectively (Table 6). 


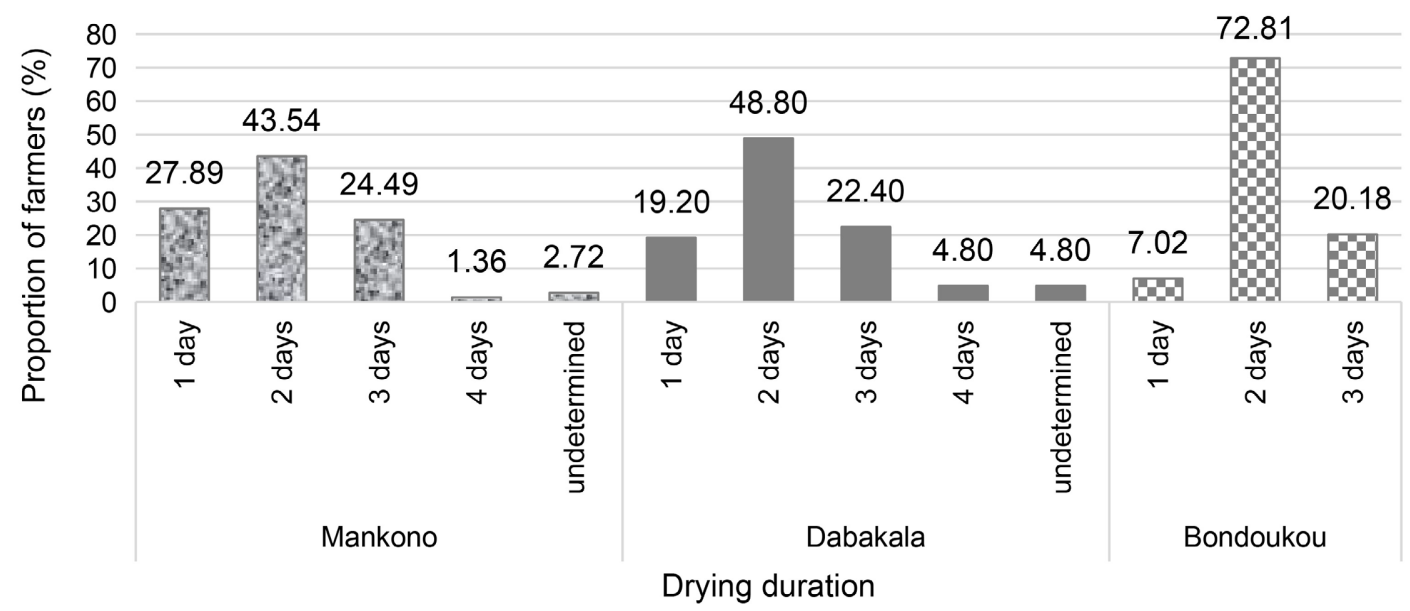

Figure 6. Drying duration of cashew nuts in the main production areas.

Table 6. Sorting of defective nuts during the drying.

\begin{tabular}{lccccc}
\hline & & Bondoukou (\%) & Dabakala (\%) & Mankono (\%) & Average (\%) \\
\hline \multirow{2}{*}{ Sorting defective nuts } & Yes & $77.19^{\mathrm{a}}$ & $66.40^{\mathrm{b}}$ & $31.97^{\mathrm{c}}$ & 58.52 \\
& No & $22.81^{\mathrm{a}}$ & $33.60^{\mathrm{b}}$ & $68.03^{\mathrm{c}}$ & 42.48 \\
\hline
\end{tabular}

Data are average values \pm standard deviation. ${ }^{\mathrm{a}, \mathrm{b}, \mathrm{c}}$ Average of the same line with different letters are significantly different $(\mathrm{p}<0.05)$.

\subsubsection{Storage Process}

At least $50 \%$ of interviewed farmers stored their product and the duration varies from 1 to 6 months (Table 7). Forty point thirty five percent (40.35\%) of farmers from Bondoukou were concerned against only $16.08 \%$ in Dabakala and $17.69 \%$ in Mankono respectively. But, the duration of storage was stronger in Mankono till 5 months with an average against only 2 months in Bondoukou and Dabakala. And during nut storage, $11 \%$ of the producers interviewed revealed that they used chemicals to control pests in the warehouse. In Bondoukou, only $1.75 \%$ of farmers used chemicals and they concerned exclusively (100\%) repellent products. The repellent products used have been observed in Dabakala (52\%) but not in Mankono (Table 7).

Table 7. Storage duration and pesticides use or not.

\begin{tabular}{cccccc}
\hline & & Mankono & Dabakala & Bondoukou & Total \\
\hline Nuts storage & Yes (\%) & $17.69^{\mathrm{b}}$ & $16.80^{\mathrm{b}}$ & $40.35^{\mathrm{a}}$ & 24.09 \\
& No (\%) & $82.31^{\mathrm{b}}$ & $83.20^{\mathrm{b}}$ & $59.65^{\mathrm{a}}$ & 75.91 \\
\hline $\begin{array}{c}\text { Storage duration } \\
\text { (Month) }\end{array}$ & Min & 2 & 1 & 1 & 1 \\
& Max & 6 & 6 & 5 & 6 \\
\hline $\begin{array}{c}\text { Pesticides use } \\
\text { Average }\end{array}$ & $4.79 \pm 1.4^{\mathrm{b}}$ & $2.09 \pm 1.90^{\mathrm{a}}$ & $2.07 \pm 1.20^{\mathrm{a}}$ & $3.67 \pm 1.90$ \\
\hline & Yes (\%) & 19.05 & 12.80 & 1.75 & 11.20 \\
\hline
\end{tabular}


Continued

\begin{tabular}{cccccc}
\hline & Insecticides & $82.14^{\mathrm{c}}$ & $44^{\mathrm{b}}$ & $0^{\mathrm{a}}$ & 61.82 \\
$\begin{array}{c}\text { Nature of the } \\
\text { chemicals used (\%) }\end{array}$ & Rodenticide & $7.14^{\mathrm{b}}$ & $0^{\mathrm{a}}$ & $0^{\mathrm{a}}$ & 3.64 \\
& Repellent products & $0^{\mathrm{c}}$ & $52^{\mathrm{b}}$ & $100^{\mathrm{a}}$ & 27.27 \\
& Not identified & $10,71^{\mathrm{c}}$ & $4^{\mathrm{b}}$ & $0^{\mathrm{a}}$ & 7.27 \\
\hline
\end{tabular}

Data are average values \pm standard deviation. ${ }^{\mathrm{a}, \mathrm{b}, \mathrm{c}}$ Average of the same line with different letters are significantly different $(\mathrm{p}<0.05)$.

\section{Discussion}

The present study focused on the agricultural practices of cashew nuts famers in Côte d'Ivoire through the three main regions of production namely Bondoukou, Mankono and Dabakala, which represent $40 \%$ of annual cashew nuts production according to Ivorian cashew regulation organism. Since pre or postharvest practices could influence the quality of crops [28] [29] [30], our study is thus justified. In addition, practices of cashew farmers could be also influenced by their culture and communities and the agricultural practices applied to local preponderant crops such as cotton in Mankono and cocoa in Bondoukou. Moreover, there was no scientific data available on the description of agricultural practices in cashew cultivation in Côte d'Ivoire and very few studies in this field from Africa countries producers were reported or published [19]. Finally, Côte d'Ivoire is the first cashew nuts producer and exporter in the world so the implementation of the basis of certification appeared inevitable in cashew sector. We thought that the improvement of cashew production process should involve firstly a best acknowledge of good agricultural practices. In this context, for the present study, three groups of variables have been followed namely the information on the plantations, the harvest and postharvest practices.

Concerning the typology of cashew plantations in Côte d'Ivoire, more than half of farmers adopted plants association which could be intermittent or annual. Crops frequently associated with cashew were yams, maize, peanuts, rice, cassava, cotton and millet. Previous studies have shown that crops cultivation associations or intercropping have interesting prospects such as soils fertility, control weeds in cashew plantation, avoiding malnutrition and the diversification of farm incomes [31] [32] [33]. Indeed, depending on soil and climatic conditions and local situations, annual crops like tapioca, pulses, turmeric, ginger, yam, maize, etc., can be grown as inter crops. Leguminous crops such as groundnuts, horse gram, cowpea and beans are very suitable for inter cropping [31]. However, farmers may pay attention to the inter-cropping practice because possible problems of competition between several speculations have been reported, with namely a low yield or low plants growth as consequences [31] [32] [33]. For example, inter-cropping could be practiced in the first few years (4 - 5 years) when there is sufficient space between crop rows, but tall growing inter-crops like certain varieties of sorghum and millet should not be encouraged 
between young cashews, as they provide too much shade [31]. In addition, farmers must avoid plants that may host pests and diseases of cashew. Indeed, it had been reported that abundance and diversity of key cashew insect pests and diseases were influenced by agroecological zones and subzones [34]. That could enhance the use of pesticides and probably explain the abundant use of pesticide by farmers from Mankono [22]. Indeed, farmers from Mankono were also producers of cotton so they tend to use the same pesticides in cashew cultivation. In addition, they were older with large plantations and the density of workers per hectare as observed during harvesting was low in Mankono compared to those from Bondoukou and Dabakala regions. These disparities could also explain the abnormally long time of nuts picking in Mankono where nearly half of farmers collected cashew nuts at least once a week. The consequences on the quality of cashew nuts were probably fungi proliferation and mycotoxins secretion [35] but also spoilage on the farm namely changes in nuts physical and biochemical properties [19] [35] [36]. It had been recommended not to pick the nuts exceed twice a day [19] [36]. This recommendation was moderately acted in Bondoukou and Dabakala regions, so there is an actual need to improve the cashew harvesting process in Côte d'Ivoire. The harvesting process should be improved on other aspects, namely the reduction of pesticides' used by regular maintenance. Indeed, nearly all farmers from Mankono and Dabakala against only one-tenth of farmers from Bondoukou practiced chemical treatment of their farms during harvesting. Herbicides such as controversial glyphosate and 2,4-D were majors chemicals used [22] and that could affect the quality of cashew if the presence of their residues in cashew nuts exceeded the Maximum Residue Levels (MRLs). However, the use of fungicide in Mankono could be explained by the long delay of nuts picking since famers have observed molds proliferation. Other disparity in harvesting practice was the nuts sorting or not before drying. Most of farmers from Bondoukou adopted this practice, in contrast to Mankono where a significant number of farmers ignored it. The sorting was one possibility to improve cashew nuts quality because farmers could remove defective or immature nuts and avoid favorable conditions to mold colonization [35]. Indeed, a recent study in Nigeria, a West African county, revealed that eleven fungal species belonging to five species were isolated from the cashew nuts, with Aspergillus favus, Rhizopus oryzae, and Fusarium oxysporum having the highest percentage occurrence of 50\% [37]. Farmers from Mankono used fungicides probably to counteract mold proliferation since the nut picking delay was very long up to one week.

Concerning the post-harvest processing, our study focused on drying and storage process. Different dryers have been found, namely drying rack table, concrete floor and tarpaulins, the same dryers used in cocoa beans drying in Côte d'Ivoire [38]. In the study to evaluate the influence of fermentation and drying materials on the contamination of cocoa beans by ochratoxin A (OTA), it had been reported that the type of dryers did not affect OTA concentrations 
[38]. But, occurrence of aflatoxins in cashew nuts had been reported in Nigeria with concentration ranged between $0.1-6.8$ and $29-33.78 \mathrm{ng} \cdot \mathrm{kg}^{-1}$ for cashew nuts and groundnuts, respectively and the values of aflatoxins concentrations could vary according to cashew origin [37]. Considering the possible contamination of cashew nuts by aflatoxins [37] [39] [40], it had been recommended that nuts drying should be done on hard ground, preferably, concrete floors and nuts should be spread thinly on the ground or should not exceed $20 \mathrm{~kg} / \mathrm{m}^{2}$ or a finger depth and must be turned constantly about twice to three times a day for uniform drying [19] [35] [36]. The duration of drying is also a factor which, if not adequate, could lead to contamination of nuts by aflatoxins. Our study revealed a risk of contamination in Bondoukou since more than $70 \%$ of farmers dried their nuts only for 2 days while it recommended 3 - 4 days [19] [36] or 5 - 7 days [35] to reach a moisture level of $10 \%-12 \%$ or until the kernels rattle in the shell. However, the absence of sorting during the drying process in order to remove defective nuts in Mankono was an insufficiency because the presence of only one moldy nut could affect several nuts and thus decreased the quality. Finally, cashew nuts storage process has been investigated in our study and at least $50 \%$ of farmers stored their product during a duration varying from 1 to 6 months. Farmers from Mankono stored their products longer by using pesticides namely insecticides revealing risk to occurrence of their residues in cashew nuts.

\section{Conclusion}

This study described the cultivation practices of cashew nut producers and contributed to the establishment of a database on the determinants of the quality of nuts produced in Côte d'Ivoire. The present study showed real disparities in the techniques used by producers in Mankono, Dabakala and Bondoukou. In the Mankono area, pesticides were used extensively in cashew cultivation. The time taken to pick up the nuts was long and they were not sorted once picked up. This resulted in a high rate of defective nuts. The practices in Dabakala were similar to those observed in Mankono with the exception of the separation of defective nuts at the drying stage. Producers in the Bondoukou area had a relatively short drying time, while cashew nuts could be stored for a fairly long time. It is therefore necessary to assess the real impact of pre- and post-harvest practices in Côte d'Ivoire on cashew nut quality in order to improve its competitiveness and sustainability.

\section{Declaration of Competing Interest}

This research did not receive any specific grant from funding agencies in the public, commercial, or not-for-profit sectors.

\section{Acknowledgements}

We are really grateful to ANADER (“Agence National d'Appui au Développe- 
ment Rural") and COPABO ("Société Coopérative des Producteurs Agricoles de Bondoukou”) for its help in rural area.

\section{Statement of Credit Authors' Contribution}

Yao Stéphane KOFFI: Methodology, Supervision, Software, Formal Analysis, Resources, Data Retention, Research and acquisition of funding. James Halbin KOUADIO: Project Administration, Conceptualization, Methodology, Resources, Data Retention, Supervision, Writing original project, Research and acquisition of funding. Joseph SOYA: Methodology, Supervision.

\section{Conflicts of Interest}

The authors declare no conflicts of interest regarding the publication of this paper.

\section{References}

[1] De Carvalho Nilo Bitu, V., et al. (2015) Ethnopharmacological Study of Plants Sold for Therapeutic Purposes in Public Markets in Northeast Brazil. Journal of Ethnopharmacology, 172, 265-272. https://doi.org/10.1016/j.jep.2015.06.022

[2] Schweiggert, R.M., et al. (2016) Carotenoids, Carotenoid Esters, and Anthocyanins of Yellow-, Orange-, and Red-Peeled Cashew Apples (Anacardium occidentale L.). Food Chemistry, 200, 274-282. https://doi.org/10.1016/j.foodchem.2016.01.038

[3] Dedehou, E., Dossou, J. and Soumanou, M.M. (2015) Etude Diagnostique des technologies de transformation de la pomme de cajou en jus au Bénin. International Journal of Biological and Chemical Sciences, 9, Article No. 1. https://doi.org/10.4314/ijbcs.v9i1.32

[4] Issaka, D.K. (2019) Production de noix de cajou au Bénin: État des lieux et perspectives pour 2019. 22.

[5] Sinan, A. and Zoumana, C. (2017) Diagnostic Study of Obstacles Related to the Production of Cashew Nuts in the Odienne Region in the North of the Cote d'Ivoire. International Journal of Agricultural Policy and Research, 5, 129-137.

[6] Ducroquet, H., Tillie, P., Elouhichi, K. and Gomez, Y.P.S. (2017) L'agriculture de la Côte d'Ivoire à la loupe: Etat des lieux des filières de production végétales and animales and revue des politiques agricoles. Publications Office of the European Union, EUR-Scientific and Technical Research Reports. https://publications.jrc.ec.europa.eu/repository/handle/111111111/51249

[7] Bassett, T.J., Koné, M. and Pavlovic, N.R. (2018) Power Relations and Upgrading in the Cashew Value Chain of Côte d'Ivoire. Development and Change, 49, 1223-1247. https://doi.org/10.1111/dech.12400

[8] Afouda, L.C.A., Zinsou, V., Balogoun, R.K., Onzo, A. and Ahohuendo, B.C. (2013) Inventaire des agents pathogènes de l'anacardier (Anacardium occidentale L.) au Bénin. Bulletin de la Recherche Agronomique du Bénin (BRAB), No. 73, 19.

[9] N'depo, O.R., et al. (2017) Inventaire des insectes ravageurs du verger anacardier dans les régions deBounkani, Gontougo and Indénie-Djablun au Nord-Est en Côte d'Ivoire-Recherche Google. Afrique Science, 13, 333-343.

[10] Kyriacou, M.C., Leskovar, D.I., Colla, G. and Rouphael, Y. (2018) Watermelon and Melon Fruit Quality: The Genotypic and Agro-Environmental Factors Implicated. 
Scientia Horticulturae, 234, 393-408. https://doi.org/10.1016/j.scienta.2018.01.032

[11] Di Vittori, L., Mazzoni, L., Battino, M. and Mezzetti, B. (2018) Pre-Harvest Factors Influencing the Quality of Berries. Scientia Horticulturae, 233, 310-322. https://doi.org/10.1016/j.scienta.2018.01.058

[12] Smith, O., et al. (2019) A Domestication History of Dynamic Adaptation and Genomic Deterioration in Sorghum. Nature Plants, 5, Article No. 4. https://doi.org/10.1038/s41477-019-0397-9

[13] Kuyu, C.G. and Bereka, T.Y. (2020) Review on Contribution of Indigenous Food Preparation and Preservation Techniques to Attainment of Food Security in Ethiopian. Food Science \& Nutrition, 8, 3-15. https://doi.org/10.1002/fsn3.1274

[14] Manizan, A.L., Akaki, D., Piro-Metayer, I., Montet, D., Brabet, C. and Koffi-Nevry, R. (2018) Évaluation des pratiques post récolte favorables à la contamination de l'arachide par les mycotoxines dans trois régions de Côte d'Ivoire. Journal of Applied Biosciences, 124, 12446-12454. https://doi.org/10.4314/jab.v124i1.6

[15] Magan, N. and Aldred, D. (2007) Post-Harvest Control Strategies: Minimizing Mycotoxins in the Food Chain. International Journal of Food Microbiology, 119, 131-139. https://doi.org/10.1016/j.ijfoodmicro.2007.07.034

[16] NEPAD (2013) Technologies to Reduce Post-Harvest Food Losses, African Ministerial Council on Science and Technology.

[17] Kasso, M. and Bekele, A. (2018) Post-Harvest Loss and Quality Deterioration of Horticultural Crops in Dire Dawa Region, Ethiopia. Journal of the Saudi Society of Agricultural Sciences, 17, 88-96. https://doi.org/10.1016/j.jssas.2016.01.005

[18] Olayemi, F.F., Adegbola, J.A. and Daura, A.M. (2010) Assessment of Post-Harvest Challenges of Small Scale Farm Holders of Tomotoes, Bell and Hot Pepper in Some Local Government Areas of Kano State, Nigeria. Bayero Journal of Pure and Applied Sciences, 3, 39-42. https://doi.org/10.4314/bajopas.v3i2.63217

[19] Gyedu-Akoto, E., Lowor, S.T., Assuah, M., Kumi, W. and Dwomoh, E.A. (2014) Assessment of Post-HARVEST Handling Effects on Quality of Cashew Nuts and Kernels in Ghana. Journal of Scientific Research \& Reports, 3, 953. https://www.researchgate.net/publication/282733604 Assessment of Post-HARVE ST Handling Effects on Quality of Cashew Nuts and Kernels in Ghana https://doi.org/10.9734/JSRR/2014/8242

[20] Mieu, B. (2018) Noix de cajou: La Côte d'Ivoire peine à vendre sa production-Jeune Afrique. JeuneAfrique.com. https://www.jeuneafrique.com/562012/economie/noix-de-cajou-la-cote-divoire-pei ne-a-vendre-sa-production

[21] Kouakou, C.K., et al. (2018) Agro-Morphological Characterization of Cashew (Anacardium occidentale L.) Ecotypes from North-Central of Côte d'Ivoire. Fruits, 73, 255-264. https://doi.org/10.17660/th2018/73.5.1

[22] Yao, S.K., James, H.K., Yeboue-Kouame, B.Y., Joseph, S. and Assanvo, J.E. (2020) Study of Pesticides Use Conditions in Cashew Production in Côte d'Ivoire. JTEHS, 12, 1-9.

[23] Rongead (2010) L'out-turn ou comment mesurer la qualité de l'anacarde?

[24] Touré, M., et al. (2018) Traits morphométriques and germination des noix de Anacarde occidentale L. au Sénégal.

[25] Adeigbe, O., et al. (2016) Quantitative Descriptors of Cashew Nut Categories in Nigeria: Providing Indices for Superior Nut Selection. Journal of Agricultural and Biological Science, 11, 142-148. 
[26] Ajayi, O.C. (2005) Biological Capital, User Costs and the Productivity of Insecticides in Cotton Farming Systems in Sub-Saharan Africa. International Journal of Agricultural Sustainability, 3, 154-166. https://doi.org/10.1080/14735903.2005.9684753

[27] Kayungura, C. (2009) Cours de recherches scientifiques and descente sur terrain, inédit ISIG/GOMA.

https://www.memoireonline.com/06/11/4576/m Connaissancesattitudes-et-pratiqu es-des-eleves-des-ecoles-secondaires-de-lairede-sante-de-19.html

[28] Asogwa, E.U., Hammed, L.A. and Ndubuaku, T.C.N. (2008) Integrated Production and Protection Practices of Cashew (Anacardium occidentale) in Nigeria. African Journal of Biotechnology, 7, Article No. 25.

[29] Mas, N. (2019) Pratiques culturales phyto-fruits 2015: Pêchers. http://www.epsilon.insee.fr:80/jspui/handle/1/107085

[30] Bugaud, C., Ocrisse, G., Salmon, F. and Rinaldo, D. (2014) Bruise Susceptibility of Banana Peel in Relation to Genotype and Post-Climacteric Storage Conditions. Postharvest Biology and Technology, 87, 113-119. https://doi.org/10.1016/j.postharvbio.2013.08.009

[31] Visalakshi, M., Jawaharlal, M. and Ganga, M. (2015) Intercropping in Cashew Orchards. Acta Horticulturae, 1080, 295-298. https://doi.org/10.17660/ActaHortic.2015.1080.38

[32] Hien, E. (2004) Dynamique du carbone dans un acrisol ferrique du Centre-Ouest du Burkina Faso: Influence des pratiques culturales sur le stock and la qualité de la matière organique. Ecole Nationale supérieure Agronomique de Montpellier.

[33] Cesar, J. and Gouro, A. (2001) Productions fourragères en zone tropicale. Les légumineuses fourragères herbacées. CIRDES, 8.

[34] Agboton, B.V., et al. (2013) Bioecology of Some Key Cashew Insect Pests and Diseases in Diverse Habitats and Landscapes in Tanzania. Journal of Applied Entomology, 137, 782-789. https://doi.org/10.1111/jen.12069

[35] Matimelo, M. (2017) Harvesting and Drying of Cashew Nuts. Plantwise, 1.

[36] FAO (2012) Guide to Harvesting and Post-Harvest Handling of Cashew Nuts. Gesellschaft für Internationale Zusammenarbeit (GIZ)-African Cashew Initiative.

[37] Adetunji, M.C., Alika, O.P., Awa, N.P., Atanda, O.O. and Mwanza, M. (2018) Microbiological Quality and Risk Assessment for Aflatoxins in Groundnuts and Roasted Cashew Nuts Meant for Human Consumption. Journal of Toxicology, 2018, Article ID: 1308748. https://www.hindawi.com/journals/jt/2018/1308748 https://doi.org/10.1155/2018/1308748

[38] Dano, S.D., et al. (2013) Influence of Fermentation and Drying Materials on the Contamination of Cocoa Beans by Ochratoxin A. Toxins, 5, 2311-2323. https://doi.org/10.3390/toxins5122310

[39] Kujbida, P., et al. (2019) Risk Assessment of the Occurrence of Aflatoxin and Fungi in Peanuts and Cashew Nuts. Brazilian Journal of Pharmaceutical Sciences, 55, e18135. https://doi.org/10.1590/s2175-97902019000118135

[40] Milhome, M.A.L., Lima, C.G., de Lima, L.K., Lima, F.A.F., Sousa, D.O.B. and Nascimento, R.F. (2014) Occurrence of Aflatoxins in Cashew Nuts Produced in Northeastern Brazil. Food Control, 42, 34-37.

https://doi.org/10.1016/j.foodcont.2014.01.033 